\title{
The Effect of pH of the Sodium Hypochlorite on Smear Layer Removal
}

\author{
Branislav Karadžić ${ }^{1}$, Nina Dimitrijević 1 , Dragica Manojlović ${ }^{1}$, Tomislav Trišović ${ }^{2}$ \\ ${ }^{1}$ Department for Restorative Dentistry and Endodontics, School of Dentistry, \\ University of Belgrade, Belgrade, Serbia; \\ ${ }^{2}$ Technological Institute SANU, Belgrade, Serbia
}

\begin{abstract}
SUMMARY
Introduction Canal irrigation is an important segment of endodontic treatment. The aim of this study was to assess the efficacy of $0.5 \% \mathrm{NaOCl}$ solutions of different $\mathrm{pH}$ values on smear layer removal.

Material and Methods Thirty-two freshly extracted single rooted teeth with gangrenous pulp were used in the study. The samples were divided into four groups of eight teeth in each. Four solutions of $0.5 \% \mathrm{NaOCl}$ having pH values 5 , 7, 9 and 12 respectively, were used during chemomechanical instrumentation with hand instruments and using step back technique. SEM analysis was done to assess the quality of smear layer removal in apical, middle and coronal part of root canal. Presence and quantity of smear layer and detritus was quantified using the scale from 1 to 5 .

Results SEM analysis results showed similar results for $0.5 \% \mathrm{NaOCl}$ solutions of different $\mathrm{pH}$ values in root canal cleaning with no statistically significant differences.
\end{abstract}

Conclusion The most effective cleaning root canal was achieved with $0.5 \% \mathrm{NaOCl}$ solution of $\mathrm{pH} 5$.

Keywords: sodium hypochlorite; smear layer

\section{INTRODUCTION}

Adequate root canal cleaning and shaping followed by copious irrigation are main factors for successful endodontic treatment [1]. Irrigation plays an important role during biomechanical preparation of the root canal. It facilitates instrumentation (lubricant effect), changes chemically and dissolves debris and smear layer from the canal walls. Also, it eliminates organic and inorganic content from the root canal $[2,3,4]$ and acts against microorganisms $[5,6]$.

$\mathrm{NaOCl}$ is the most commonly used for root canal irrigation [7] and its $\mathrm{pH}$ is between 11 and 12. It is in use in concentrations from $0.5-5.25 \%$ and is considered to be irrigant of choice in contemporary endodontic therapy [1, 8]. $\mathrm{NaOCl}$ dissolves pulp tissue and organic components of smear layer [9]. However, $\mathrm{NaOCl}$ can not completely remove smear layer (other than superficial layer), and therefore it is used in combination with chelate solutions (EDTA and citric acid) [10].

$\mathrm{NaOCl}$ has strong antibacterial effect for a short contact time. Several in vitro studies and one clinical study confirmed antifungal effect of $\mathrm{NaOCl}$ on Candida albicans [11-14]. Many Gram-negative anaerobic bacteria showed high sensitivity to $\mathrm{NaOCl}$ in concentrations of $0.5 \%$ to $5 \%$ [13], while Enterococcus faecalis is resistant to action of these solutions. In comparative studies on the effect of different irrigants against biofilms, solutions of $1 \% \mathrm{NaOCl}$ and $6 \%$ killed $99.7 \%$ of bacteria after contact time of 1 or 5 minutes, while $2 \%$ of chlorhexidine and MTAD killed only $60.5 \%$ [15].

Antibacterial effect and tissue dissolving ability of $\mathrm{NaOCl}$ depend on its concentration, however, with higher concentrations cytotoxicity is increased, too $[16,17]$. Significant difference between the $0.5 \%, 1 \%, 2.5 \%$ and $5 \% \mathrm{NaOCl}$ against $E$. faecalis and anaerobic flora was not found in in vivo studies [18]. This justifies use of $\mathrm{NaOCl}$ in concentrations of $0.5 \%$ and $1 \%$ as optimal in clinical praxis [19]. These concentrations represent good balance between the tissue dissolving ability, antimicrobial activity and biocompatibility.

Instead of using high concentration of $\mathrm{NaOCl}$, the effectiveness of this solution can be improved by increasing temperature [19]. It was confirmed that $1 \% \mathrm{NaOCl}$ solution at a temperature of $45^{\circ} \mathrm{C}$ dissolves the same amount of tissue as the concentration of $5.25 \% \mathrm{NaOCl}$ at $20^{\circ} \mathrm{C}$, and $1 \% \mathrm{NaOCl}$ at $60^{\circ} \mathrm{C}$ is more efficient than $5.25 \% \mathrm{NaOCl}$ solution [20]. Heated solution shows much better antimicrobial effect, however, if solution was heated and not used, it would lose its efficiency and could not be used anymore [21].

In addition to concentration and temperature, the duration of irrigation is also important. Studies have shown that $\mathrm{NaOCl}$ in concentrations of $1-5 \%$ is able to eliminate all microorganisms for 60 minutes, while 30 minutes is short period. This means that the contact time must be between 30 and 60 minutes [22]. 
Quantity of irrigant is also important. Increasing the amount correlates with reduction of microorganisms and cleanliness of canals [23]. Yamada et al [11] proposed $10-20 \mathrm{ml}$ of irrigant for each canal with mandatory final flushing.

If $\mathrm{NaOCl}$ enters periapical tissue, it can cause severe pain that lasts a few minutes. It can also cause swelling, emphysema, paresthesia, periapical tissue necrosis and abundant hemorrhage through the root canal [16].

The aim of this study was to assess the efficacy of $0.5 \%$ $\mathrm{NaOCl}$ solutions of different $\mathrm{pH}$ values on smear layer removal.

\section{MATERIAL AND METHODS}

Thirty-two freshly extracted single rooted teeth with gangrenous pulp were used in the study.

The crowns of the tooth were removed and chemomechanical instrumentation using manual instruments and step back technique and $0.5 \% \mathrm{NaOCl}$ solutions of different $\mathrm{pH}$ values was performed. After each instrument, canal was rinsed with $2 \mathrm{~mL}$ of $\mathrm{NaOCl}$. After completed instrumentation each canal was rinsed with $10 \mathrm{ml}$ of $\mathrm{NaOCl}$. Teeth were allocated into four groups (8 teeth in each group) and rinsed with the following solutions: Group I: $0.5 \% \mathrm{NaOCl}$ solution, $\mathrm{pH} 5$; Group II: $0.5 \% \mathrm{NaOCl}$ solution, $\mathrm{pH}$ 7; Group III: 0.5\% NaOCl solution, pH 9; Group IV: non buffered $0.5 \% \mathrm{NaOCl}$ solution, $\mathrm{pH} 12$.

Electrolysis of diluted $\mathrm{NaOCl}$ solution was achieved in aqueous solutions where concentration of $\mathrm{NaOCl}$ was $3 \%(30 \mathrm{~g} / \mathrm{l})$. All solutions used in this study were prepared by dissolving chemicals in distilled water $(18 \mathrm{M} \Omega)$ three times distilled using the device from water company Milipore, USA. Electrolysis was performed in reaction container having capacity of 5 liters and electric current of $20 \mathrm{~A}\left(100 \mathrm{~mA} / \mathrm{cm}^{2}\right)$ in the time period of 4 hours. After the electrolysis solution was transferred to five containers with volume of $1000 \mathrm{ml}$ each. Adjusting the $\mathrm{pH}$ value in these containers was achieved using hydrochloric acid for acid solutions and sodium hydroxide for the base solutions. The $\mathrm{pH}$ values of the solutions at $298 \mathrm{~K}$ were $4.8,5$, 8,10 , and 12 . Solutions were buffered and $\mathrm{pH}$ value was measured by digital $\mathrm{pH}$ meter from Iskra company.

At the end of the experiment, the canal was dried and two grooves on buccal and lingual surfaces were created. Tooth was frozen in liquid nitrogen, cut into two halves using chisel. The inner wall of the canal was preserved. The samples were coated with palladium-gold in high vacuum using the device JEOL-SS-RT, Japan. The prepared samples

Table 1. The effect of $\mathrm{NaOCl}$ on the coronal part of the root canal Tabela 1. Efekat rastvora $\mathrm{NaOCl}$ na koronarnom delu kanala korena zuba

\begin{tabular}{|c|c|c|c|c|}
\hline \multirow{2}{*}{$\begin{array}{l}\text { Coronal part } \\
\text { Koronarni deo }\end{array}$} & \multicolumn{4}{|c|}{$\mathrm{NaOCl}$} \\
\hline & $\mathrm{pH}=5$ & $\mathrm{pH}=7$ & $\mathrm{pH}=9$ & $\mathrm{pH}=12$ \\
\hline $\begin{array}{l}\text { Average (SD) } \\
\text { Prosek (SD) }\end{array}$ & $1.75(0.96)$ & $2.75(0.96)$ & $3.25(0.96)$ & $2.25(1.89)$ \\
\hline $\begin{array}{l}\text { Median (range) } \\
\text { Medijana (opseg) }\end{array}$ & $1.50(1-3)$ & $2.50(2-4)$ & $3.50(2-4)$ & $1.50(1-5)$ \\
\hline
\end{tabular}

were observed under the microscope JEOL-JSM-S800, Japan at three levels of root canal: coronal, middle and apical at different magnifications. The presence and quantity of smear layer and debris on the canal walls was rated by the scale proposed by Hülsmann et al [24].

\section{RESULTS}

SEM analysis of the coronal third of the canal confirmed the most efficient smear layer removal using $0.5 \% \mathrm{NaOCl}$ solution of $\mathrm{pH} 5$, then using the solution $\mathrm{pH} 7$ and $\mathrm{pH} 12$. The least effective was $0.5 \%$ solution of $\mathrm{pH} 9$. The difference was not statistically significant (Table 1, Figures 1 and 2).

SEM analysis of the middle third of the canal also showed that the most efficient smear layer removal was achieved with $\mathrm{NaOCl}$ solution $\mathrm{pH}$, then with the solution of $\mathrm{pH} 7$ and $\mathrm{pH}$ 9. The least effective was $0.5 \%$ solution with $\mathrm{pH} 12$. The difference was not statistically significant (Table 2, Figures 3 and 4).

SEM analysis of the apical third of the canal showed the most effective smear layer removal with $\mathrm{NaOCl}$ solu-

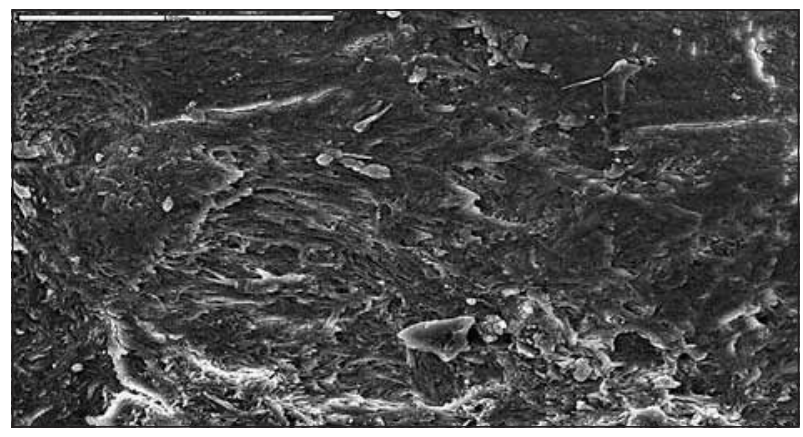

Figure 1. Coronal part of the root canal flushed with $\mathrm{NaOCl}(\mathrm{pH} 7)$. The canal walls are completely covered by homogenous smear layer and no dentin openings could be seen. More than $50 \%$ of the walls is covered with the debris. Grade 4 (magnification 500x).

Slika 1. Koronarni deo kanala korena zuba ispiran rastvorom $\mathrm{NaOCl}$ ( $\mathrm{pH}$ 7). Zidovi kanala potpuno prekriveni homogenim razmaznim slojem i nema otvorenih dentinskih kanala. Više od 50\% zidova kanala prekriveno debrisom. Ocena 4 (uveličanje 500x).

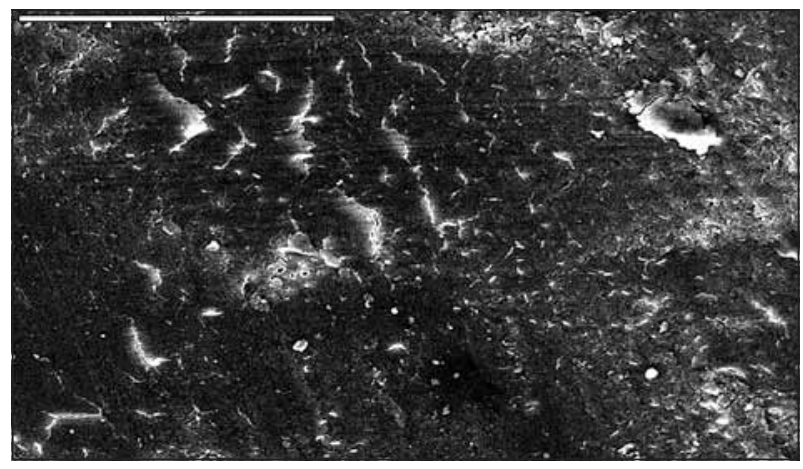

Figure 2. Coronal part of the root canal flushed with $\mathrm{NaOCl}(\mathrm{pH}$ ) . The canal walls are completely covered by homogenous smear layer and no dentin openings could be seen. More than $50 \%$ of the walls is covered with the debris. Grade 4 (magnification 500x).

Slika 2. Koronarni deo kanala korena zuba ispiran rastvorom $\mathrm{NaOCl}$ ( $\mathrm{pH}$ 9). Zidovi kanala potpuno prekriveni homogenim razmaznim slojem i nema otvorenih dentinskih kanala. Više od 50\% zidova kanala prekriveno debrisom. Ocena 4 (uveličanje 500x). 
Table 2. The effect of $\mathrm{NaOCl}$ on the middle part of the root canal Tabela 2. Efekat rastvora $\mathrm{NaOCI}$ na srednjem delu kanala korena zuba

\begin{tabular}{|l|c|c|c|c|}
\hline \multirow{2}{*}{$\begin{array}{l}\text { Middle part } \\
\text { Srednji deo }\end{array}$} & \multicolumn{4}{|c|}{$\mathbf{~ N a O C l}$} \\
\cline { 2 - 5 } & $\mathbf{p H}=\mathbf{5}$ & $\mathbf{p H = 7}$ & $\mathbf{p H = 9}$ & $\mathbf{p H}=\mathbf{1 2}$ \\
\hline $\begin{array}{l}\text { Average (SD) } \\
\text { Prosek (SD) }\end{array}$ & $1.25(0.50)$ & $2.25(0.50)$ & $2.00(0.00)$ & $3.00(1.41)$ \\
\hline $\begin{array}{l}\text { Median (range) } \\
\text { Medijana (opseg) }\end{array}$ & $1.00(1-2)$ & $2.00(2-3)$ & $2.00(2-2)$ & $2.50(2-5)$ \\
\hline
\end{tabular}

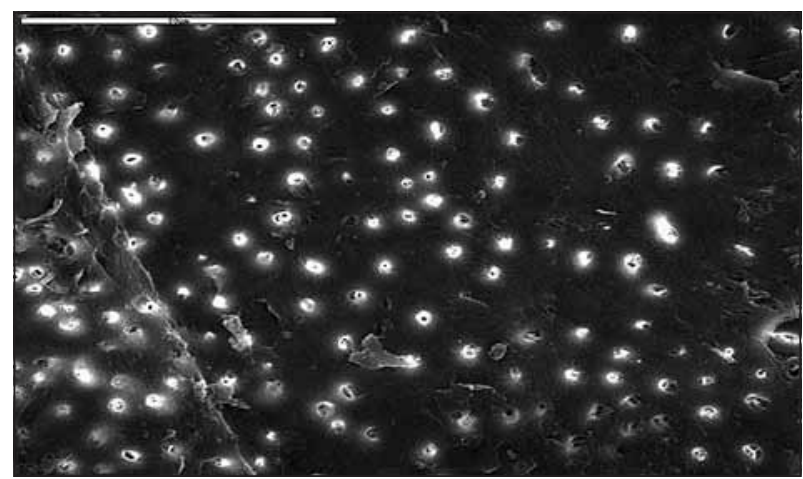

Figure 3. Middle part of the root canal flushed with $\mathrm{NaOCl}(\mathrm{pH}$ ). Smear layer is removed and dentin tubules are open. Canal walls are clean without the debris. Grade 1 (magnification 1000x).

Slika 3. Srednji deo kanala korena zuba ispiran rastvorom $\mathrm{NaOCl}(\mathrm{pH}$ 5). Nema razmaznog sloja i svi dentinski kalanići su otvoreni. Zidovi su čisti skoro bez naslaga debrisa. Ocena 1 (uveličanje 1000×).

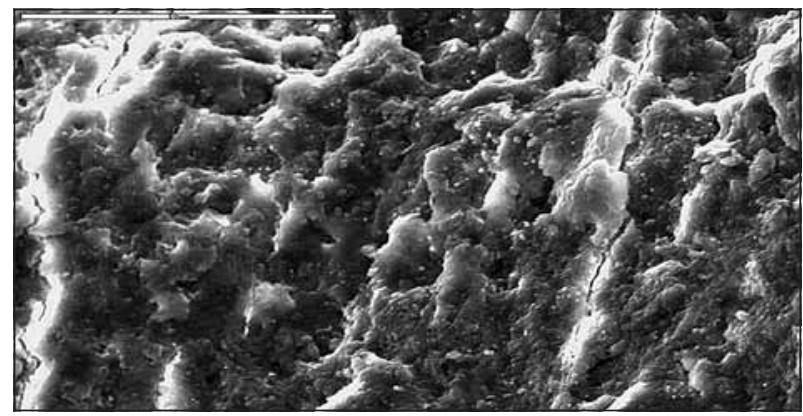

Figure 4. Middle part of the root canal flushed with unbuffered $\mathrm{NaOCl}$ ( $\mathrm{pH}$ 12). Non-homogenous smear layer is present covering the walls of the root canal. Grade 5 (magnification 1000x).

Slika 4. Srednji deo kanala korena zuba ispiran nepuferovanom rastvorom $\mathrm{NaOCl}$ ( $\mathrm{pH}$ 12). Veoma izražen nehomogen razmazni sloj koji potpuno pokriva zidove kanala korena zuba. Ocena 5 (uveličanje $1000 \times)$.

tion $\mathrm{pH} 9, \mathrm{pH} 5$ and $\mathrm{pH}$ 7. The least effective was the $0.5 \%$ solution with $\mathrm{pH} 12$. The difference was not statistically significant (Table 3, Figure 5).

\section{DISCUSSION}

After endodontic treatment of the root canal, the debris and smear layer remain on the surface of the canal. Smear layer is composed of inorganic and organic substances, contains remnants of pulp, microorganisms and their products as well as a part of mineral origin and dentin [25]. Because of possible contamination and adverse effect on the outcome of endodontic treatment smear layer should be removed from the canal walls. Previous methods for
Table 3. The effect of $\mathrm{NaOCl}$ on the apical part of the root canal Tabela 3. Efekat rastvora $\mathrm{NaOCI}$ na apeksnom delu kanala korena zuba

\begin{tabular}{|l|c|c|c|c|}
\hline \multirow{2}{*}{$\begin{array}{l}\text { Apical part } \\
\text { Apeksni deo }\end{array}$} & $\mathbf{4 H = 5}$ & $\mathbf{p H = 7}$ & $\mathbf{p H = 9}$ & $\mathbf{p H}=\mathbf{1 2}$ \\
\cline { 2 - 5 } & $\mathbf{p H}$ & $\mathbf{4}$ \\
Proserage (SD) & $3.00(0.00)$ & $3.00(0.82)$ & $2.75(0.96)$ & $3.25(1.26)$ \\
\hline $\begin{array}{l}\text { Median (range) } \\
\text { Medijana (opseg) }\end{array}$ & $3.00(3-3)$ & $3.00(2-4)$ & $2.50(2-4)$ & $3.00(2-5)$ \\
\hline
\end{tabular}

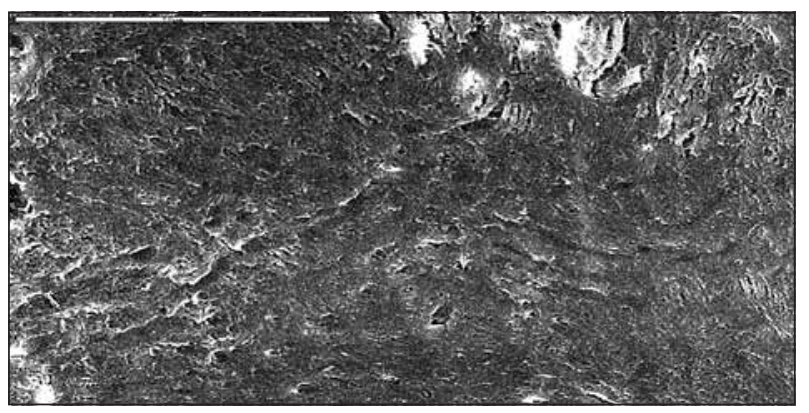

Figure 5. Apical part of the root canal flushed with $\mathrm{NaOCl}(\mathrm{pH} 5)$. Smear layer covers the walls of the canal and some dentin tubules are open. Less than $50 \%$ of the walls is covered with the debris. Grade 3 (magnification 1000x).

Slika 5. Apeksni deo kanala korena zuba ispiran rastvorom $\mathrm{NaOCl}$ ( $\mathrm{pH}$ 5). Razmazni sloj pokriva zidove kanala, a poneki dentinski kanalić je otvoren. Veće količine debrisa pokrivaju manje od 50\% zidova. Ocena 3 (uveličanje 1000x).

smear layer removal (chemical, ultrasonic, laser) were not satisfactory [26].

This research was conducted to investigate the effect of $0.5 \% \mathrm{NaOCl}$ solutions of different $\mathrm{pH}$ values on smear layer removal. First use of buffered $\mathrm{NaOCl}$ solutions was by Dakine who buffered $0.5 \% \mathrm{NaOCl}$ with sodium bicarbonate and created $\mathrm{NaOCl}$ solution with $\mathrm{pH}$ 9. This solution was more efficient on necrotic then living tissue; it had significantly reduced cytotoxicity and showed good antimicrobial effect [27].

The current study showed that the $\mathrm{NaOCl}$ solution ( $\mathrm{pH}$ 5 ) was the most effective in removing smear layer in the coronal and middle part of the root canal. In acidic solutions of $\mathrm{NaOCl}, \mathrm{pH} 5$, the electrolysis of $\mathrm{NaCl}$ creates the greatest amount of hypochlorous acid $(\mathrm{HClO})$ on anode in relation to hypochlorous anion ( $\left.\mathrm{ClO}^{-}\right)$. Hypochlorous acid has three times stronger effect on the organic matter than hypochlorous anion. Hypochlorous acid hydrolysis on hydrochloric acid and oxygen, which in reaction with $\mathrm{HCl}$ releases chlorine $\left(\mathrm{Cl}_{2}\right)$. Chlorine penetration into living cells causes dysfunction of cell enzymes and amino acids causing bacterial death in root canal $[27,28]$. All $\mathrm{NaOCl}$ solutions release active chlorine ( $\mathrm{HClO}$ and $\mathrm{ClO}^{-}$), in acid solutions amount of active chlorine increases while at higher $\mathrm{pH}$ increases the amount of hypochlorous anion. Results from the current study showed no significant difference in dissolving ability of different $\mathrm{NaOCl}$ solutions and therefore conclusion could be that quantitative relation of $\mathrm{HClO}$ and $\mathrm{ClO}^{-}$is not of primary importance, the amount of released active chlorine is also important [27]. This fact is in favor of need for copious irrigation during root canal treatment with fresh hypochlorite solution. 
In the apical part lesser amount of debris and smear layer was found compared to the other parts of teeth, rinsed by $\mathrm{NaOCl}$ solutions of higher $\mathrm{pH}$ values. The results of this study suggested that the canal walls debris was removed mostly by dissolving ability of $\mathrm{NaOCl}$. Several studies confirmed no significant difference in tissue dissolving ability of $\mathrm{NaOCl}$ of different $\mathrm{pH}$ [27].

Dissolving ability primarily depends on the amount of released chlorine gas, which denatures proteins and thus dissolves tissue from the canal wall $[28,29]$. Limited or incomplete effect on smear layer removal is due to the presence of mineral components derived from dentin in smear layer. Mineral components provide strength and homogeneity to smear layer and can be removed only by combination with chelate agents (EDTA, $10 \%$ citric acid) $[10,29]$. However, despite the fact that buffered $0.5 \% \mathrm{NaOCl}$ solution of $\mathrm{pH} 5$ showed the best cleaning effect of the canal wall, it was not statistically significant to $\mathrm{NaOCl}$ solutions of different $\mathrm{pH}$ values. This conclusion and other states justify use of commercial $\mathrm{NaOCl}$ solution (home bleach) diluted by water ( $\mathrm{pH} 12$ ) for root canal irrigation [27].

\section{CONCLUSION}

Based on presented and analyzed results on the efficacy of $0.5 \% \mathrm{NaOCl}$ solutions of different $\mathrm{pH}$ values, it can be concluded that there was no significant difference between the solutions in smear layer removal. $0.5 \% \mathrm{NaOCl}$ solution $(\mathrm{pH} 5)$ showed slightly better cleaning and open dentin tubules could be seen in some parts of the root canal.

\section{REFERENCES}

1. Ayhan H, Sultan N, Cirak M, Ruhi Z, Bodur H. Antimicrobial effects of various endodontic irrigants on selected microorganisms. Int Endod J. 1999; 32:99-102.

2. Walker D. Irrigating the pulp space. Endod Prac. 1999; 2(1):8-12.

3. Liolios E, Economides N, Parissis-Messimeris S, Boutsioukis A. The effectiveness of thraa irrigating solutions on root canal cleaning after hand and mechanical preparation. Int Endod J. 1997; 30:51-7.

4. Yoshida T, Shibata T, Shionhara T, Gomyo S, Sekine I. Clinical evaluation of the eficacy of EDTA solution as an endodontic irrigant. J Endod. 1995; 21:592-3.

5. Brown DC, Moore BK, Brown CE Jr, Newton CW. An in vitro study of sodium hypochlorite during endodontic canal preparation. J Endod. 1995; 21:587-91.

6. Siren EK, Haapasalo MPP, Ranta K, Salimi P, Kerosuo EN. Microbiological findings and clinical treatment procedures in endodontic cases selected for mocrobiological investigation. Int Endod J. 1997; 38:91-5.

7. Bystrom A, Sundqvist G. Bacteriologic evaluation of the efficacy of mechanical root canal instrumentation in endodontic therapy. Scand J Dent Res. 1981; 89:321-8.

8. Jeansonne MJ,White RR. A comparasion of $2 \%$ chlorhexidine gliconate and $5.25 \%$ sodium hypochlorite as antimicrobial endodontic irrigants. J Endod.1994; 20:276-8.
9. Naenni N, Thoma K, Zehnder M. Soft tissue dissolution capacity of currently used and potential endodontic irrigants. J Endod. 2004; 30:785-7.

10. Silva IA, Leonardo MR, Assed S, Tanomaru Filho M. Histological study of the effect of some irrigating solutions on bacterial endotoxin in dogs. Braz Dent J. 2004; 15:109-14.

11. Yamada RS, Armas A, Goldman M, Lin PS. A scanning electron microscopic comparation of a high volume final flush with several irrigating solutions: Part 3. J Endod. 1983; 9:137-42.

12. Waltimo TM, Orstavik D, Sirén EK, Haapasalo MP. In vitro susceptibility of Candida albicans to four disinfectants and their combinations. Int Endod J. 1999; 32:421-9.

13. Vianna ME, Gomes BP, Berber VB, Zaia AA, Ferraz CC, de SouzaFilho FL. In vitro evaluation of the antimicrobial activity of chlorhexidine and sodium hypochlorite. Oral Surg Oral Med Oral Pathol Oral Radiol Endod. 2004; 97:79-84.

14. Peciuliene V, Reynaud A, Balciuniene I, Haapasalo M. Isolation of yeasts and enteric bacteria in root-filled teeth with chronic apical periodontitis. Ist Endod J. 2001; 34:429-34.

15. Dunavant TR, Regan JD, Glickman GN, Solomon ES, Honeyman AL. Comparative evaluation of endodontic irrigants against Enterococcus faecalis biofilms. J Endod. 2006; 32:527-31.

16. Chang YC, Huang FM, Tai KW, Chou MY. The effect of sodium hypochlorite and chlorhexidine on cultured human periodontal ligament cells. Oral Surg Oral Med Oral Pathol Oral Radiol Endod. 2001; 92:446-50.

17. Cunningham WT, Balekjian AY. Effect of temperature collagen-dissolving ability of sodium hypochlorite endodontic irrigant. Oral Surg Oral Med Oral Pathol. 1980; 49:175-7.

18. Bystrom A, Sundqvist G. The antibacterial action of sodium hypochlorite and EDTA in 60 cases of endodontic therapy. Ind Endod J. 1985; 18:35-40.

19. Zehnder M. Root canal irrigants. J Endod. 2006; 32:389-98.

20. Sirtes G, Waultimo T, Schaetzle M, Zehnder $M$. The effects of temperature on sodium hypochlorite short-term stability, pulp dissolution capacity, and antimicrobial efficacy. J Endod. 2005; 31:669-71.

21. Cunningham WT, Jozeph SW. Effects of temperature on the bactericidal action of sodium hypochlorite endodontic irrigant. Oral Surg Oral Med Oral Pathol. 1980; 50:569-71.

22. Spratt DA, Pratten J, Wilson M, Gulabivala K. An in vitro evaluation of the antimicrobial efficacy of irrigants on biofilms of root canal isolates. Int Endod J. 2001; 34:300-7.

23. Sedgley CM, Applegate B, Nagel AC, Hall D. Real-time imaging and quantification of bioluminescent bacteria in root canals in vitro. J Endod. 2004; 30:893-8.

24. Hülsmann M, Rümellin C,Schäfers F. Root canal cleanliness after preparation with different Endodontic handpieces and hand instruments: a comparative SEM investigation. Int End J. 1997; 23:301-6.

25. Pashley DH. Smear layer: overview of structure and funtion. Proc Finn Dent Soc. 1992; 88:215-24.

26. Torabinejad M, Handysides R, Khademi A, Bakland LK. Clinical implications of the smear layer in endodontics: a review. Oral Surg Oral Med Oral Pathol Oral Radiol Endod. 2002; 94:658-66.

27. Zehnder M, Kosicki D, Luder H, Sener B, Waltimo T. Tissue-dissolving capacity and antibacterial effect of buffered and unbuffered hypochlorite solutions. Oral Surg Oral Med Oral Pathol Oral Radiol Endod. 2002; 94:756-62.

28. Gordon TM, Damato D, Christner P. Solvnt effect of various dilutions of sodium hypochlorite on vital and necrotic tissue. J Endod. 1981; 7:466-9.

29. Karadžić B, Polić Dj. SEM studija efekta različitih iriganasa na razmazni sloj i detritus zidova obradjenog inficiranog kana korena zuba. Stomatološki glasnik Srbije. 1993; 40:209-12. 


\title{
Uticaj pH vrednosti rastvora natrijum-hipohlorita na uklanjanje razmaznog sloja
}

\author{
Branislav Karadžić 1 , Nina Dimitrijević1, Dragica Manojlović1, Tomislav Trišović \\ ${ }^{1}$ Klinika za bolesti zuba, Stomatološki fakultet, Univerzitet u Beogradu, Beograd, Srbija; \\ 2Tehnološki institut SANU, Beograd, Srbija
}

\begin{abstract}
KRATAK SADRŽAJ
Uvod Irigacija kanala je značajan segment svakog endodontskog lečenja zuba. Cilj ovog rada je bio da se proveri efekat čišćenja zida kanala korena zuba nakon ispiranja rastvorom od 0,5\% natrijum-hipohlorita $(\mathrm{NaOCl})$ različitih pH vrednosti.

Materijal i metode rada Kao materijal korišćena su 32 sveže izvađena jednokorena zuba sa gangrenoznom pulpom. Uzorci su svrstani u četiri grupe od po osam zuba. Za ispiranje tokom mehaničko-medikamentne obrade tzv. step-back tehnikom i ručnim endodontskim instrumentima primenjena su četiri rastvora koncentracije od $0,5 \% \mathrm{NaOCl}$ sa puferovanim rastvorima čija je $\mathrm{pH}$ vrednost bila 5, 7 i 9, odnosno nepuferovanim rastvorom pH vrednosti 12. SEM analizom je proveren kvalitet čišćenja zida kanala od razmaznog sloja u apeksnom, srednjem i koronarnom delu kanala korena. Procena zastupljenosti i količine razmaznog sloja i detritusa vršena je ocenjivanjem na skali od 1 do 5.

Rezultati Rezultati SEM analiza su pokazali slično dejstvo različitih pH vrednosti rastvora $\mathrm{NaOCl} u$ čišćenju kanala korena zuba bez statističke značajne razlike.
\end{abstract}

Zaključak Najefikasnije čišćenje kanala korena ostvareno je $0.5 \%$ rastvorom $\mathrm{NaOCl}$ čiji je pH 5 .

Ključne reči: natrijumhipohlorit; razmazni sloj

\section{UVOD}

Adekvatno čišćenje i oblikovanje kanala korena zuba i obilna irigacija tokom instrumentacije glavni su faktori uspeha endodontskog lečenja [1]. Irigacija je sastavni deo biomehaničke preparacije kanala i ima zadatak da olakša pokretanje instrumenata u kanalu (lubrikantno svojstvo), hemijski izmeni i rastvori debris i razmazni sloj sa zidova kanala, olakša eliminaciju organskog i neorganskog sadržaja sa zidova kanala $[2,3,4]$ i deluje antiseptično na zaostale mikroorganizme u parakanalnom sloju $[5,6]$.

Natrijum-hipohlorit $(\mathrm{NaOCl})$ je najčešće korišćeno sredstvo za ispiranje kanala korena zuba, a njegova $\mathrm{pH}$ vrednost je između 11 i 12 [7]. Koristi se u koncentracijama od 0,5\% do $5,25 \%$ i smatra se irigansom izbora u savremenoj endodontskoj terapiji $[1,8]$. NaOCl razlaže pulpno tkivo i organske komponente dentina i razmaznog sloja [9]. Ipak, $\mathrm{NaOCl}$ ne može potpuno da ukloni razmazni sloj (osim površinskog sloja), pa se zato koristi u kombinaciji sa helatima (EDTA i limunskom kiselinom) [10].

$\mathrm{NaOCl}$ ima jako antibakterijsko dejstvo s kratkim kontaktnim vremenom. Nekoliko istraživanja in vitro i jedna klinička studija potvrdili su dejstvo $\mathrm{NaOCl}$ na Candida albicans [1114]. Mnoge Gram-negativne anaerobne bakterije pokazale su visoku osetljivost na $\mathrm{NaOCl} \mathrm{u} \mathrm{koncentracijama} \mathrm{0,5-5 \%} \mathrm{[13],}$ dok je Enterococcus faecalis otporan na delovanje ovog rastvora. U komparativnim studijama o efektu različitih irigansa na biofilm, rastvori $\mathrm{NaOCl}$ od $1 \%$ i $6 \%$ su uništili $99,7 \%$ bakterija posle kontaktnog vremena od jednog ili pet minuta, dok je dvoprocentni rastvor hlorheksidina i MTAD uništio samo $60,5 \%$ bakterija [15].

Dejstvo $\mathrm{NaOCl}$ na bakterije i razlaganje tkiva zavisi i od koncentracije, iako se s većim koncentracijama povećava i citotoksičnost $[16,17]$. U istraživanjima in vivo nisu uočene značajne razlike između koncentracija od 0,5\%, 1\%, 2,5\% i 5\% NaOCl na E. faecalis i anaerobnu floru [18]. Time je potvrdeno da su koncentracije od 0,5\% i 1\% najbolje za kliničku praksu, jer čine najbolju ravnotežu između sposobnosti rastvaranja tkiva, antimikrobne aktivnosti i biokompatibilnosti [19].

Umesto primene visokih koncentracija $\mathrm{NaOCl}$, efikasnost ovoga rastvora se može poboljšati i povećanjem temperature [19]. Potvrđeno je da jednoprocentni rastvor $\mathrm{NaOCl}$ na temperaturi od $45^{\circ} \mathrm{C}$ razlaže tkivo kao i $\mathrm{NaOCl}$ koncentracije $5,25 \%$ na $20^{\circ} \mathrm{C}$, a $1 \% \mathrm{NaOCl}$ na $60^{\circ} \mathrm{C}$ je mnogo efikasniji nego „punosnažni“ rastvor $\mathrm{NaOCl}$ od 5,25\% [20]. Zagrejani rastvor pokazuje i mnogo bolje antimikrobno dejstvo, međutim, treba znati da rastvor koji se zagreje a ne iskoristi gubi efikasnost i ne može se ponovo upotrebiti [21].

Pored koncentracije i temperature, važno je i vreme trajanja irigacije. Istraživanja su pokazala da rastvoru $\mathrm{NaOCl}$ koncentracije 1-5\% treba 60 minuta da uništi sve mikroorganizme, dok je 30 minuta kratak period. To znači da kontaktno vreme mora biti između 30 i 60 minuta [22].

Količina irigansa je takođe bitna. Povećanje količine je u korelaciji sa redukcijom mikroorganizama i čistoćom kanala [23]. Jamada (Yamada) i saradnici [11] predlažu primenu 10-20 ml irigansa za svaki kanal i obavezan finalni snažni mlaz na kraju.

Ukoliko se utisne u periradikularno tkivo, $\mathrm{NaOCl}$ može da izazove jake bolove koji traju nekoliko minuta. Može da izazove otok, emfizem, parestezije, nekrozu periapeksnog tkiva i obilna krvarenja kroz kanal korena zuba [16].

Cilj ovog rada je bio da se SEM analizom proveri efekat uklanjanja razmaznog sloja sa zidova kanala korena primenom rastvora od $0,5 \% \mathrm{NaOCl}$ različitih $\mathrm{pH}$ vrednosti.

\section{MATERIJAL I METODE RADA}

Kao materijal u istraživanju korišćena su 32 sveže izvađena jednokorena zuba sa gangrenozno raspadnutom pulpom. 
Pre početka instrumentacije, dijamantskim diskom je odsečena klinička kruna zuba, a kanali su endodontski obrađeni rastvorom $\mathrm{NaOCl}$ različitih $\mathrm{pH}$ vrednosti. Kanali su obrađeni tzv. step-back tehnikom ručnim instrumentima. Posle svake promene instrumenta kanal je ispiran sa $2 \mathrm{ml} \mathrm{NaOCl}$. Nakon mehaničke obrade svaki kanal je ispiran sa $10 \mathrm{ml}$ rastvora. Uzorci zuba su svrstani u četiri grupe od po osam zuba. Prva grupa uzoraka je ispirana rastvorom $\mathrm{NaOCl}$ čija je $\mathrm{pH}$ vrednost bila 5, druga grupa rastvorom $\mathrm{pH}$ vrednosti 7, treća sa $\mathrm{pH}$ 9, a četvrta nepuferovanim rastvorom $\mathrm{NaOCl} \mathrm{pH}$ vrednosti 12 .

Elektroliza razblaženih rastvora $\mathrm{NaOCl}$ je ostvarena u vodenim rastvorima gde je koncentracija $\mathrm{NaOCl}$ bila 3\% (30 g/l). Rastvori korišćeni u ovom istraživanju pravljeni su od p.a. hemikalija. Hemikalije su rastvarane u destilovanoj vodi (18 M $\Omega$ ) koja je tri puta obrađena u uređaju za prečišćavanje vode (Millipore, USA). Elektroliza je izvođena u temperovanoj reakcionoj posudi zapremine $51 \mathrm{~s}$ jačinom struje od $20 \mathrm{~A}\left(100 \mathrm{~mA} / \mathrm{cm}^{2}\right)$ u trajanju od četiri časa. Nakon elektrolize rastvor iz reakcione posude je prebačen u pet mesgolben posuda zapremine od po $1000 \mathrm{ml}$. Podešavanje $\mathrm{pH}$ vrednosti u tim posudama ostvareno je hlorovodoničnom kiselinom za kisele rastvore i natrijumhidroksidom za bazne rastvore. Vrednost $\mathrm{pH}$ rastvora na $298 \mathrm{~K}$ bila je 4,8, 5, 8, 10 i 12. Rastvori su bili puferovani, a vrednost $\mathrm{pH}$ je merena digitalnim $\mathrm{pH}$-metrom (Iskra).

Nakon preparacije, kanal je osušen, a zatim je koren zasecan dijamantskim diskom vestibularno i oralno. Potom je zub zamrzavan u tečnom azotu i dletom cepan na dve polovine, čime se očuvao unutrašnji zid kanala. Nakon toga uzorci su naparavani paladijum-zlatom u visokom vakuumu (aparat JEOL-SSRT, Japan). Pripremljeni uzorci su posmatrani na mikroskopu (JEOL-JSM-S800, Japan) na tri nivoa kanala korena (koronarnom, srednjem i apeksnom) i pri različitim uveličanjima. Ocena zastupljenosti i količine razmaznog sloja i detritusa vršena je na skali koju su predložili Hilsman (Hülsmann) i saradnici [24].

\section{REZULTATI}

SEM analizom koronarne trećine kanala potvrđeno je da je najefikasnije čišćenje kanala ostvareno rastvorom $\mathrm{NaOCl}$ čija je $\mathrm{pH}$ vrednost bila 5, potom rastvorom $\mathrm{pH}$ vrednosti $7 \mathrm{i} 12$. Najmanje efikasan je bio rastvor od 0,5\% čija je pH vrednost bila 9. Međutim, razlika nije bila statistički značajna (Tabela 1; Slike 1 i 2).

SEM analiza srednje trećine kanala je takođe pokazala da je najefikasnije čišćenje kanala ostvareno rastvorom $\mathrm{NaOCl}$ čija je $\mathrm{pH}$ vrednost bila 5, zatim rastvorom $\mathrm{pH}$ vrednosti 7 i 9 . Najmanje efikasan je bio rastvor od 0,5\% čija je pH vrednost bila 12. Razlika nije bila statistički značajna (Tabela 2 i slike 3 i 4).

SEM analizom apeksne trećine kanala pokazalo se da je u ovom delu kanala najefikasnije čišćenje kanala ostvareno rastvorom $\mathrm{NaOCl}$ čija je $\mathrm{pH}$ vrednost bila 9 , zatim rastvorom $\mathrm{pH}$ vrednosti 5 i 7 . Najmanje efikasan je bio rastvor od 0,5\% čija je $\mathrm{pH}$ vrednost bila 12. Razlika ni ovde nije bila statistički značajna (Tabela 3; Slika 5).

\section{DISKUSIJA}

Nakon endodontske obrade kanala korena zuba debris i razmazni sloj u različitoj meri ostaju na površinama kanala. Takav razmazni sloj sačinjen je od neorganskih i organskih materija i sadrži ostatke pulpe, mikroorganizme i njihove proizvode, kao i mineralni deo koji potiče od dentina [25]. Zbog moguće kontaminacije i lošeg efekta na ishod endodontskog lečenja, razmazni sloj se mora ukloniti iz kanalnog sistema zuba. Dosadašnje metode uklanjanja razmaznog sloja (hemijske, ultrazvučne, laserske) nisu pokazale potpunu efikasnost u uklanjanju ovoga sloja [26].

Ovo istraživanje je urađeno da bi se ispitao efekat rastvora od $0,5 \% \mathrm{NaOCl}$ različitih $\mathrm{pH}$ vrednosti na razmazni sloj na zidu kanala korena zuba nakon ispiranja. Prvi koji je koristio puferovane rastvore $\mathrm{NaOCl}$ bio je Dakin, koji je 0,5\% $\mathrm{NaOCl}$ puferovao sa sodom bikarbonom i dobijao rastvor $\mathrm{NaOCl} \mathrm{pH}$ vrednosti 9. Takav rastvor je pokazao agresivniji efekat na nekrotično, nego na živo tkivo, značajno je smanjio citotoksičnost $\mathrm{i}$ ispoljio dobro antimikrobno dejstvo [27].

Naše istraživanje je pokazalo da je rastvor $\mathrm{NaOCl} \mathrm{pH}$ vrednosti 5 bio najefikasniji u uklanjanju razmaznog sloja u koronarnom i srednjem delu. Kod kiselih rastvora $\mathrm{NaOCl} \mathrm{pH}$ vrednosti 5 elektrolizom $\mathrm{NaCl}$ na anodi nastaje najveća količina hipohloraste kiseline $(\mathrm{HClO}) \mathrm{u}$ odnosu na hipohloritni anjon $\left(\mathrm{ClO}^{-}\right.$ ), koja ima trostruko jači efekat na organske materije od $\mathrm{ClO}^{-}$. $\mathrm{HClO}$ se hidrolizuje na hlorovodoničnu kiselinu i kiseonik, a u daljoj rekciji sa $\mathrm{HCl}$ se oslobađa i hlor $\left(\mathrm{Cl}_{2}\right)$. Prodiranjem hlora u žive ćelije dolazi do izbacivanja iz funkcije ćelijskih enzima i aminokiselina, a time do smrti bakterija u kanalu korena $[27,28]$. Naime, kod svih rastvora $\mathrm{NaOCl}$ se oslobađa tzv. aktivni hlor ( $\mathrm{HClO}$ i $\mathrm{ClO}^{-}$), ali je kod kiselijih rastvora to nešto više, pa kod većih $\mathrm{pH}$ vrednosti raste i količina $\mathrm{ClO}^{-}$. Imajući $\mathrm{u}$ vidu ove rezultate, gde nije nađena značajna razlika u organolitičkoj efikasnosti, može se reći da količinski odnos $\mathrm{HClO}$ i $\mathrm{ClO}^{-}$nije od primarnog značaja, već da je to količina oslobođenog aktivnog hlora [27]. Ovaj podatak govori u prilog potrebi za obilnim ispiranjem kanala korena tokom endodontske obrade svežim rastvorom hipohlorita.

U apeksnom delu je uočena manja količina debrisa i razmaznog sloja u poređenju sa delovima zuba koji su ispirani rastvorima $\mathrm{NaOCl}$ većih $\mathrm{pH}$ vrednosti. Rezultati ovog istraživanja potvrđuju da je debris sa zidova kanala uglavnom uklonjen primenom ovih rastvora zahvaljujući njegovim organolitičkim sposobnostima. Malobrojna ispitivanja dejstva rastvora različitih $\mathrm{pH}$ vrednosti pokazuju da nema razlike u organolitičkom efektu ovih rastvora kanala korena [27].

Rastvarački efekat prevashodno zavisi od količine oslobođenog gasa hlora, koji denaturiše proteine i tako razlaže naslage na zidu kanala $[28,29]$. Ograničen efekat, odnosno nepotpun efekat uklanjanja razmaznog sloja, posledica je zastupljenosti mineralne komponente razmaznog sloja koja potiče od dentina i daje čvrstoću i homogenost razmaznom sloju, pa se jedino može ukloniti u kombinaciji s helatnim sredstvima (EDTA, desetoprocentna limunska kiselina) [10, 29]. Međutim, i pored toga što je puferovani rastvor od $0,5 \% \mathrm{NaOCl} \mathrm{pH}$ vrednosti 5 pokazao najbolji efekat čišćenja zida kanala, to nije bilo statistički značajno u poređenju s rastvorima $\mathrm{NaOCl}$ drugih $\mathrm{pH}$ vrednosti. Ovaj navod, kao i drugi navodi, opravdavaju primenu komercijalnih rastvora $\mathrm{NaOCl}$ (kućno belilo) razblaženih vodom ( $\mathrm{pH} 12)$ za čišćenje kanala korena zuba [27]. 


\section{ZAKLJUČAK}

$\mathrm{Na}$ osnovu rezultata istraživanja efekata čišćenja zidova kanala korena zuba rastvorom $\mathrm{NaOCl}$ različitih $\mathrm{pH}$ vrednosti, može se zaključiti da ne postoji značajna razlika u kvalitetu čišćenja zidova kanala korena između njih. Nešto bolji efekat čišćenja pokazao je rastvor pH vrednosti 5, gde su se na zidu kanala mogli uočiti mestimično otvoreni i čisti dentinski kanalići. 